\title{
Assessment of hybrid rice (Oryza sativa) under farmers' condition in the east and south eastern coastal plain zone of Odisha
}

\author{
S.C. SAHOO*, M. BEHERA AND P.K. BANERJEE \\ Directorate of Extension Education, Orissa University of Agriculture and Technology, BHUBANESWAR \\ (ODISHA) INDIA (Email : akaskanya@gmail.com)
}

\begin{abstract}
An on-farm experiment was conducted during Kharif season of 2013 in four villages of Khorda district in east and south eastern coastal plain zone of Odisha to assess the performance of rice hybrid Rajalaxmi in the farmers' field. The results revealed that there was increase in 60.07 per cent grain yield, 47.8 per cent straw yield and 68.6 per cent net profit due to the hybrid as compared to prevailing variety MTU 1010. The increase in yield of hybrid variety was due to 56.1 per cent more number of panicles $/ \mathrm{m}^{2}, 22.8$ per cent more grains / panicle and 2.98 per cent heavier grains than the high yielding variety.
\end{abstract}

Key Words : Hybrid rice Rajalaxmi, Grain yield, Net profit

View Point Article : Sahoo, S.C., Behera, M. and Banerjee, P.K. (2015). Assessment of hybrid rice (Oryza sativa) under farmers' condition in the east and south eastern coastal plain zone of Odisha. Internat. J. agric. Sci., 11 (1): 204-206.

Article History : Received : 04.08.2014; Accepted : 28.12.2014

\footnotetext{
* Author for correspondence
} 